\title{
PENINGKATAN KEMAMPUAN MENGENAL LAMBANG BILANGAN 1-10 MELALUI MEDIA BALOK CUISENAIRE PADA ANAK USIA 4-5 TAHUN DI TK AT-TOYYIBAH
}

\author{
(Penelitian Tindakan Kelas pada Anak Usia 4-5 Tahun di TK At-Toyyibah \\ Kecamatan Sukarame Kabupaten Tasikmalaya)
}

\author{
Gilar Gandana ${ }^{1}$, Oyon Haki Pranata ${ }^{2}$, Tannie Yulia Danti ${ }^{3}$ \\ ${ }^{1}$ Program Studi PGPAUD UPI Kampus Tasikmalaya \\ ${ }^{2}$ Program Studi PGSD UPI Kampus Tasikmalaya \\ ${ }^{3}$ Program Studi PGPAUD UPI Kampus Tasikmalaya \\ Email: gilar@upi.edu
}

(Received: Mei 2017; Accepted: Mei 2017; Published: Juni 2017)

\begin{abstract}
This study aims to improve the ability to recognize the symbol of the number 1-10 through the medium blocks of cuisenaire in children aged 4-5 years in kindergarten At TK At-Toyyibah, District Sukarame, Tasikmalaya. The type of research used is classroom action research done collaboratively with Kemmis and Mc Taggart research models. This study was carried out in three cycles. Research subjects were teachers and children aged 4-5 years with a total of 12 children, namely: 9 boys and 3 girls. The instrument used is the observation sheet (check list), which consists of teacher activity observation sheet and children activity. Data collection techniques through observation, interviews, and documentation. Data analysis technique is done d descriptively qualitative. The indicator of success in this study, if the ability to recognize the symbol of the number $1-10$ in children reached $75 \%$ percentage. The ability to recognize the 1-10 number symbols in 4-5 years old children has a significant increase each cycle. The results of observations from pre-action to cycle I showed an increase of only $1 \%$ with the average percentage of pre-action by $35 \%$ of capable children and $65 \%$ of children who have not been able to cycle I by $36 \%$ of capable children and $64 \%$ of children has not been able to. From cycle I the average percentage of $36 \%$ of children are able and $64 \%$ of children who have not been able to cycle to 65\% capable children and 35\% of children who have not been able. Then from cycle II the average percentage of $65 \%$ of children capable and $35 \%$ of children who have not been able to cycle II of $83 \%$ capable children and $17 \%$ of children who have not been able and have achieved success indicators. Thus, it can be concluded that the media blocks of cuisenaire can increase the ability to recognize the symbol of the number 1-10 in children aged 4-5 years in kindergarten At-Toyyibah, District Sukarame, Tasikmalaya.
\end{abstract}

Keywords: The ability to recognize the symbol of the number 1-10, The media beam cuisenaire

\begin{abstract}
Abstrak
Penelitian ini bertujuan untuk meningkatkan kemampuan mengenal lambang bilangan 1-10 melalui media balok cuisenaire pada anak usia 4-5 tahun di TK At-Toyyibah, Kecamatan Sukarame, Kabupaten Tasikmalaya. Jenis penelitian yang digunakan yaitu penelitian tindakan kelas yang dilakukan secara kolaboratif dengan model penelitianKemmis dan Mc Taggart. Penelitian ini dilaksanakan ke dalam tiga siklus. Subjek penelitian yaitu guru dan anak usia 4-5 tahundengan jumlah 12 anak, yaitu: 9 anak laki-laki dan 3 anak perempuan. Instrumen yang digunakan yaitu lembar observasi (check list), yang terdiri dari lembar observasi aktivitas guru dan aktivitas anak.Teknik pengumpulan data melalui observasi, wawancara, dan dokumentasi. Teknik analisis data dilakukan secara deskriftif kualitatif. Indikator keberhasilan dalam penelitian ini, apabila kemampuan mengenal lambang bilangan 1-10 pada anak mencapai persentase 75\%. Kemampuan mengenal lambang bilangan 1-10 pada anak usia 4-5 tahun mengalami peningkatan yang signifikan setiap siklusnya. Hasil observasi dari pra tindakan ke siklus I menunjukkan peningkatan walaupun hanya $1 \%$ dengan rata-rata persentase pada pra tindakan sebesar $35 \%$ anak yang mampu dan $65 \%$ anak yang belum mampu ke siklus I sebesar $36 \%$ anak yang mampu dan $64 \%$ anak yang belum mampu. Dari siklus I ratarata persentase sebesar 36\% anak yang mampu dan 64\% anak yang belum mampu ke siklus II sebesar 65\% anak yang mampu dan 35\% anak yang belum mampu. Kemudian dari siklus II rata-rata persentase sebesar sebesar $65 \%$ anak yang mampu dan 35\% anak yang belum mampu ke siklus III sebesar 83\% anak yang mampu dan 17\% anak yang belum mampu dan telah mencapai indikator keberhasilan. Dengan demikian, dapat disimpulkan bahwa media balok cuisenaire dapat meningkatkan kemampuan mengenal lambang bilangan 1-10 pada anak usia 4-5 tahun di TK At-Toyyibah, Kecamatan Sukarame, Kabupaten Tasikmalaya.
\end{abstract}

Kata kunci: Kemampuan mengenal lambang bilangan 1-10, Media balok cuisenaire 


\section{PENDAHULUAN}

Pentingnya mengembangkan kemampuan kognitif dalam bidang matematika, yang salah satunya yaitu kemampuan mengenal lambang bilangan 1-10 pada anak usia dini. Keterampilan ini sangat dibutuhkan dalam kehidupan seharihari, karena ini merupakan dasar dari pengembangan kemampuan matematika pada anak maupun kesiapan dalam memasuki jenjang pendidikan selanjutnya. Seperti yang diungkapkan oleh World Health Organization (dalam BelindaBlevins-Knabe, dkk., 2016, hlm.53) dalam penelitian longitudinal yang telah dilakukan bahwa "early mathematics skills strongly predict later mathematics skills" yang artinya kemampuan matematika awal sangat meramalkan kemampuan matematika di kemudian hari.

Pada kenyataannya, anak di TK AtToyyibah dalam kemampuan mengenal lambang bilangan 1-10 masih rendah. Anak masih kesulitan dalam menyebut bilangan 1-10. Dan ketika satu persatu anak diminta oleh guru untuk menunjuk lambang bilangan 1-10, masih banyak anak yang bingung dan salah dalam menunjuknya. Serta masih banyak anak yang belum bisa menghubungkan lambang bilagan 110 dengan benda.

Disamping itu, kurang tersedianya media pembelajaran yang menunjang untuk proses pembelajaran di kelas. Guru dalam menyajikan pembelajaran mengenai mengenal lambang bilangan 1-10 pada anak, jarang sekali menggunakan media pembelajaran yang bervariasi. Dalam kegiatan pembelajaran, guru lebih banyak menggunakan buku tulis, papan tulis, majalah, LKA dan sedikit pula dalam menggunakan benda-benda yang ada di lingkungan sekitar sekolah.

Upaya yang dapat dilakukan untuk mengembangkan kemampuan mengenal lambang bilangan 1-10 pada anak yaitu dengan kegiatan pembelajaran yang menarik minat anak, menyenangkan, serta media pembelajaran yang tepat sesuai dengan karakteristik dan tahap perkembangan anak, agar potensi yang mereka miliki dapat berkembang secara optimal. Media pembelajaran yang dapat digunakan yaitu Media Balok Cuisenaire. Media Balok Cuisenaire merupakan salah satu alat permainan edukatif. Dengan menggunakan media ini, anak tidak hanya bermain medianya saja, tetapi dapat mengenal lambang bilangan 1-10, dan berperan penting dalam mengembangkan kemampuan dasar matematika bagi anak sendiri. Seperti diungkapkan oleh Cucu Eliyawati (2005, hlm. 69) bahwa balok cuisenaire diciptakan untuk mengembangkan kemampuan berhitung pada anak, pengenalan bilangan, dan untuk peningkatan keterampilan anak dalam bernalar. Diharapkan dengan media balok cuisenaire ini akan mempermudah dalam mengembangkan kemampuan mengenal lambang bilangan 1-10 pada anak.

\section{TINJAUAN PUSTAKA}

\section{A. Anak Usia Dini}

Menurut Undang-Undang Sistem Pendidikan Nasional Nomor. 20 Tahun 2003 ayat 1, "anak usia dini adalah anak yang masuk dalam rentang usia nol sampai dengan enam tahun."

Sujiono (2013, hlm. 6) mengungkapkan bahwa "anak usia dini adalah sosok individu yang sedang menjalani suatu proses perkembangan dengan pesat dan fundamental bagi kehidupan selanjutnya."

Usia dini merupakan usia dimana anak berada dalam masa pertumbuhan dan perkembangan yang pesat. Menurut Berk (dalam Sujiono, 2013, hlm. 6) bahwa "Pada masa ini proses pertumbuhan dan perkembangan dalam berbagai aspek sedang mengalami masa yang cepat dalam rentang perkembangan hidup manusia."

Siti Noor Hasanah (2014, hlm. 48) dalam jurnal yang berjudul Upaya Meningkatkan Kemampuan Mengenal Lambang Bilangan Melalui Media Permainan Memancing Ikan Pada Anak mengemukakan bahwa anak usia dini adalah akan yang memiliki potensi kecerdasan dan dasar-dasar perilaku yang terbentuk sejak 
rentang usia dini. Masa usia dini ini sehingga sering disebut the golden age (usia emas). Pada masa ini, stimulasi seluruh aspek perkembangan berperan penting untuk tugas perkembangan berikutnya.

Berdasarkan beberapa pendapat di atas, dapat disimpulkan bahwa anak usia dini adalah anak usia nol sampai enam tahun, yang memiliki karakteristik yang khas atau memiliki keunikan dari setiap individunya, baik secara fisik maupun psikis, dan berada pada masa pertumbuhan dan perkembangan yang pesat. Adapun aspek perkembangan pada anak usia dini, diantaranya: perkembangan moral dan agama, perkembangan fisik-motorik, perkembangan kognitif atau kecerdasan, perkembangan sosial emosional, dan perkembangan bahasa.

\section{B. Perkembangan Kognitif \\ 1. Pengertian Kognitif}

Menurut Suardiman (2003, hlm. 1) "kemampuan kognitif sering diartikan sebagai daya atau kemampuan seseorang untuk berfikir dan mengamati melihat hubungan-hubungan kegiatan yang mengakibatkan seseorang anak untuk memperoleh pengetahuan baru yang banyak didukung oleh kemampuan bertanya."

Berk (dalam Suardiman 2003, hlm. 1) juga mengungkapkan bahwa:

Kemampuan kognitif menunjuk pada proses dan produk dari dalam akal pikiran manusia yang membawanya untuk tahu. Dalam hal ini termasuk semua kegiatan mental manusia yang meliputi: mengingat, menghubungkan, mnggolong-golongkan, memberikan simbol, mengkhayal, memecahkan masalah, mencipta dan membayangkan kejadian, dan mimpi.

Sedangkan Menurut Gagne (dalam Jamaris 2006, hlm. 18) "kognitif adalah proses yang terjadi secara internal di dalam pusat susunan syaraf pada waktu manusia sedang berfikir."

Berdasarkan beberapa pendapat di atas, maka dapat disimpulkan bahwa kognitif adalah kemampuan berfikir seseorang dalam menghubungkan dan mempertimbangkan suatu pengetahuan terhadap suatu kejadian atau peristiwa sehingga orang tersebut memperoleh pengetahuan baru. Perkembangan kognitif berkaitan dengan kemampuan intelegensi seseorang. Adapun proses kognitif meliputi: aspek-aspek ingatan, simbol, pikiran, pemecahan masalah, dan penalaran.

\section{Karakteristik Perkembangan Kognitif Pada Anak Usia 4-5 Tahun}

Menurut Spodek, dkk (dalam Ramli 2005, hlm. 190) karakteristik perkembangan kognitif anak usia empat tahun, diantaranya:

1) Mampu mengidentifikasi dan menunjuk gambar yang dideskripsikan, 2) Memadankan dan memberi nama empat warna dasar 3) Membaca gambar, 4) Menghitung dan menyentuh empat benda atau lebih, 5) memberi alamat rumah dan usia, 6) Dapat menceritakan sesuatu benda terbuat dari apa, 7) Meminta penjelasan, 8) Tertarik pada kematian, 9) Menyusun katakata dan sajak, 10) Belajar membedakan antara fakta dan fantasi, 11) Suka menyelesaikan aktivitas, 12) Dapat membandingkan tiga gambar, 13) Dapat menceritakan persamaan dan perbedaan tiga dari enam gambar, 14) mengemukakan serangkaian kegiatan yang terdiri dari tiga arahan.

Kemudian Caplan dan Caplan (dalam Ramli 2005, hlm. 196) mengemukakan karakteristik perkembangan kognitif anak usia lima tahun, sebagai berikut:

1) Suka mempraktikan kemampuan intelektual, 2) Dapat menghitung dengan benar jari-jari dari satu tangan dengan menggunakan jari telunjuk dari tangan yang lain dan mengemukakan jumlahnya, 3) Dapat memadankan bilangan dengan jumlah benda, 4) Memahami beberapa kata-kata ukuran dan kuantitas, 5) Mulai melihat hubungan antara kapasitas wadah yang berbeda-beda bentuk, 6) Mempelajari hubungan antara bilangan tertulis dan terucapkan, 7) Dapat menyalin huruf-huruf besar nama tertentu, 8) Dapat memisahmisahkan benda berdasarkan ukuran, warna, 
bentuk, dll, 9) Menikmati permainan gambar lotto, permainan gambar domino, dan permainan kelompok lainnya, 10) Memisahkan dan memadankan benda-benda menurut tekstur, bau, rasa, dan sebagainya, 11) Memadankan 10 warna, 12) Memimpikan dan mendiskusikan minat jabatan.

Sedangkan dalam Peraturan Menteri Pendidikan dan Kebudayaan Republik Indonesia Nomor 137 Tahun 2014 tentang Standar Isi tentang Tingkat Pencapaian Perkembangan Anak untuk anak usia 4-5 tahun dalam lingkup perkembangan kognitif dalam berfikir simbolik, sebagai berikut:

a. Membilang banyak benda satu sampai sepuluh

b. Mengenal konsep bilangan

c. Mengenal lambang bilangan

d. Mengenal lambang huruf

\section{Tahapan Perkembangan Kognitif Pada Anak Usia 4-5 Tahun}

Salah satu teori perkembangan kognitif yang terkenal yaitu Jean Piaget. Perkembangan kognitif pada anak usia dini menurut Piaget dibagi menjadi beberapa tahapan. Menurut Piaget (dalam Upton, 2012, hlm. 151), bahwa:

Tahap perkembangan kognitif anak dapat dibagi dalam empat tahap, yaitu:

1) Tahap Sensorimotorik (0-2 tahun)

Perkembangan bergantung pada tindakan bayi menggunakan indraindra dan keterampilan-keterampilan motoriknya untuk menjelajahi dan belajar tentang dunia. Pencapaian paling penting dalam tahap perkembangan ini adalah permanensi objek.

2) Tahap Praoperasional (2-7 Tahun) Ciri utama tahap adalah berpikir simbolik dan berfikir intuitif. Berpikir simbolik yaitu kemampuan untuk secara mental merepresentasikan objek yang tidak tersaji. Sedangkan berpikir intuitif yaitu kemampuan memahami sesuatu tanpa melalui penalaran rasional dan intelektualis.
3) Tahap Operasional Konkret (7-11 tahun)

Anak-anak memahami operasi-operasi mental yang dapat diubah dan dapat mendesenter, penalaran masih terbatas karena kendati anak dapat menalar secara logis dan memahami hubunganhubungan kausal, mereka hanya dapat melakukannya jika penalaran tersebut dikaitkan dengan contoh-contoh konkret spesifik, mereka belum dapat melakukan penalaran hipotesis atau abstrak.

4) Tahap Operasional Formal (11 tahun ke atas)

Pada tahap ini pemikiran menjadi lebih logis, kemampuan untuk melakukan penalaran abstrak juga meningkat.

Dilihat dari tahapan perkembangan menurut Piaget, anak usia TK berada pada tahap praoperasional, yaitu dimana anak belum menguasai operasi mental secara logis. Tahap ini ditandai dengan berkembangnya kemampuan menggunakan sesuatu untuk mewakili sesuatu yang lain menggunakan simbol-simbol. Melalui kemampuan tersebut anak mampu untuk berimajinasi maupun berfantasi tentang berbagai hal.

\section{Kemampuan Mengenal Lambang Bilangan}

\section{Pengertian Lambang Bilangan}

St. Negoro dan B. Harahap (1998, hlm. 36) mengemukakan bahwa bilangan merupakan suatu ide yang sifatnya abstrak. Bilangan merupakan sesuatu yang hanya dapat digambarkan saja dan harus dituliskan dengan simbol agar bilangan tersebut dapat dilihat dan dibaca. bilangan dapat dinyatakan dengan lambang/ gambar bilangan. Lambang bilangan atau angka merupakan lambang-lambang untuk bilangan.

Sudaryanti (2006, hlm. 1) mengemukakan pula bahwa bilangan adalah suatu obyek matematika yang sifatnya abstrak dan termasuk dalam unsur yang tidak didefinisikan (Underfined term). Sudaryanti (2006, hlm. 4) 
menegaskan bahwa bilangan merupakan simbol dari banyaknya benda. Sedangkan Dalam menyebut bilangan dari suatu himpunan diperlukan bahasa yang sama yang berupa lambang-lambang, sehingga dapat disusun menjadi lambang bilangan.

Berdasarkan beberapa pendapat di atas, maka dapat disimpulkan bahwa bilangan adalah suatu himpunan berupa lambang atau simbol yang berkaitan erat dengan nilai yang mewakili banyaknya benda. Lambang bilangan merupakan simbol yang mewakili dari bilangan. Lambang atau simbol yang mewakili suatu bilangan disebut angka yang digunakan untuk pencacahan dan pengukuran. Lambang atau simbol bilangan ini, nantinya akan mempermudah kita dalam melakukan operasi bilangan.

\section{Ruang Lingkup Kemampuan Mengenal Lambang Bilangan Pada Anak Usia 4-5 Tahun}

Dalam Anita Yus (2005, hlm. 39) potensi yang harus dikembangkan pada diri anak itu enam aspek, yang salah satunya adalah dimensi pengembangan kognitif. Aspek-aspek perkembangan kognitif yang seharusnya dimiliki oleh anak khususnya dalam bidang matematika ialah: Menyebut atau menunjuk urutan bilangan dari 1-10, membilang (mengenal konsep bilangan dengan benda-benda), dan menghubungkan konsep bilangan dengan lambang bilangan (anak tidak disuruh menulis), mengenal konsep bilangan sama dan tidak sama, lebih dan kurang, banyak dan sedikit, menyebutkan benda yang berbentuk geometri, mengenal ukuran panjang, berat dan isi, mengenal alat untuk mengukur, mengenal penambahan dan pengurangan dengan bendabenda 1-10, mengurutkan benda 1-10 berdasarkan urutan tinggi-rendah, besar-kecil, berat-ringan, tebal-tipis, memperkirakan urutan berikutnya setelah melihat bentuk 2-3 pola yang berurutan, menyusun kepingan puzzle menjadi bentuk utuh dan mengerjakan mencari jejak (maze).
Sofia Hartati (2005, hlm. 19) mengemukakan bahwa tahapan perkembangan kognitif anak usia 4-6 tahun adalah membentuk permainan dengan kreatif, menciptakan bentuk dari tanah liat, membentuk bangunan dari balok, menyebut dan membilang 1-20, mengenal lambang bilangan, menghubungkan konsep dengan lambang bilangan, mengenal perbedaan antara sama, lebih banyak dan lebih sedikit, menjumlah dengan benda, mengenal waktu, menyusun puzzle, mengenal alat-alat ukur, mengenal asal usul terjadinya suatu hal, dan mengetahui suatu kejanggalan dari dua buah gambar.

Menurut Christopher T. Cross, dkk (2009, hlm. 129) bahwa ada empat aspek matematika yang harus dimiliki oleh anak usia dini. Diantaranya:

a. Cardinality: Children's knowledge of cardinality (how many are in a set) increases as they learn specific number words for sets of objects they see (I want two crackers).

b. Number word list: Children begin to learn the ordered list of number words as a sort of chant separate from any use of that list in counting objects.

c. 1-to-1 counting correspondences: When children do begin counting, they must use one-to-one counting correspondences so that each object is paired with exactly one number word.

d. Written number symbols: Children learn written number symbols through having such symbols around them named by their number word (That is a two).

Empat aspek matematika yang harus dimiliki oleh anak usia dini menurut Christopher T. Cross, dkk (2009, hlm. 129), dapat diartikan sebagai berikut:

a. Kardinalitas: Pengetahuan tentang kardinalitas anak, disini pengetahuan tersebut dapat meningkat ketika anak mempelajari kata-kata angka tertentu untuk suatu objek. 
b. Daftar kata nomor: Anak mulai mempelajari daftar nomor yang berurutan, dapat dilakukan dengan cara bernyanyi

c. Korelasi 1-ke-1: Saat anak mulai menghitung, Mereka harus menggunakan korespondensi satu-ke-satu sehingga masing-masing objek dapat dipasangkan dengan tepat sesuai kata dari angkanya.

d. Simbol angka tertulis: Anak belajar simbol angka tertulis, melalui simbol-simbol seperti menulis jumlah angka pada suatu benda yang ada di sekitar anak.

Berdasarkan beberapa pendapat mengenai perkembangan kognitif di atas, dapat dilihat bahwa anak usia 4-5 tahun atau kelompok A mampu mengenal konsep matematika. Anak sudah berada pada tahap mengenal lambang bilangan. Lambang bilangan yang dapat diajarkan pada anak adalah 1-10. Anak bukan hanya sekedar mengenal bilangan, namun juga mulai mengerti bahwa angka atau lambang bilangan mewakili suatu bilangan tersebut. Maka dapat disimpulkan ruang lingkup mengenal lambang bilangan 1-10 pada anak usia 4-5 tahun dalam penelitian ini adalah anak mampu menyebut urutan bilangan 1-10, menunjuk lambang bilangan 1-10, dan menghubungkan lambang bilangan 1-10 dengan benda.

\section{Tahapan Mengenal Lambang Bilangan Pada Anak Usia 4-5 Tahun}

Dalam mengenalkan lambang bilangan kepada anak bukanlah hal yang mudah. Sebelum anak dapat mengenal lambang bilangan, anak terlebih dahulu harus mengenal konsep bilangan.. Anak bukan hanya mengenal lambang bilangannya saja, tetapi juga dapat mengetahui makna dari bilangan tersebut.

Mengenalkan konsep bilangan kepada anak tidak dapat secara langsung dikenalkan kepada anak, tetapi harus melalui beberapa tahapan. Menurut Piaget (dalam Suyanto 2005, hlm. 156) dalam mengenalkan konsep bilangan pada anak usia dini tidak bisa diajarkan secara langsung, akan tetapi harus melalui beberapa tahap.
Adapun tahap yang dilakukan dalam mengenalkan konsep bilangan yang pertama yaitu anak harus mengenal terlebih dahulu bahasa simbol. Bahasa simbol ini disebut sebagai abstraksi sederhana (simple abstraction) atau abstraksi empiris. Mengenalkan bahasa simbol yaitu mengenalkan bahasa lisan dari nama bilangan dan makna dari nama bilangan tersebut, misalnya guru menyebutkan bilangan satu, dua, tiga, empat, dan seterusnya.

Pada tahap ini, anak tidak hanya mengenal bahasa simbolnya saja tetapi juga dapat mengetahui makna dari bilangan tersebut. Tahap bahasa simbol ini bisa dilakukan dengan menggunakan benda nyata atau kongkrit, dan benda yang ada di sekitar anak. Contohnya ketika guru sedang mengajar dikelas, kemudian guru membawa sebuah benda yang berjumlah tiga buah. Misalnya benda tersebut yaitu buku. Guru meletakkan buku tersebut di meja dan berkata "satu" kemudian meletekkan buku yang satunya lagi dan berkata "dua", dan meletakkan buku seterusnya dan berkata "tiga". Kemudian guru memberi intruksi kepada anak untuk melakukan hal yang sama, sampai anak tersebut memahami dan dapat melakukannya dengan baik dan benar. Sejalan dengan hal tersebut, Dehane (dalam Bob Perry, dkk, 2015, hlm. 66) mengemukakan bahwa "at the age of 3-4 years most children start to link number words to quantities, i.e. they develop awareness of numerical quantity" artinya Pada usia 3-4 tahun kebanyakan anak mulai menghubungkan katakata nomor atau angka untuk suatu jumlah, disini mereka mulai mengembangkan kesadaran akan kuantitas numerik.

Tahap kedua yaitu abstraksi reflektif (reflective abstraction). Pada tahap ini anak dilatih untuk mampu berfikir simbolis. Anak mulai menggunakan jari tangannya untuk menghitung melalui benda-benda, menggunakan jari tangan merupakan hal yang mudah dan efektif dalam melatih berhitung permulaan pada anak. contohnya menghitung jumlah wadah pensil sambil berkata satu, dua, tiga dan 
seterusnya. Disini anak mulai belajar menghubungkan jumlah benda dengan lambang bilangan. Sejalan dengan hal tersebut, Suyanto (2005, hlm. 68) mengungkapkan dalam melatih anak mengenal bilangan dapat dilakukan dengan cara, diantaranya:

Menghitung dengan jari, bermain domino, berhitung sambil bernyanyi dan berolah raga, menghitung benda-benda, menghitung di atas 10, berhitung dengan kelipatan sepuluh, mengenal operasi bilangan, mengukur panjang, mengukur volume, mengukur berat, mengenal waktu, dan mengenal mata uang., mengukur berat, mengenal waktu, dan mengenal mata uang.

Dan tahap ketiga yaitu menghubungkan antara konsep bilangan dengan lambang atau simbol bilangan. Ketika anak sudah mengetahui makna dari suatu bilangan, anak dikenalkan dengan lambang atau simbol bilangan. Contohnya anak menghubungkan sebuah benda misalnya benda tersebut adalah apel, satu buah apel dengan angka 1, dua buah apel dengan angka 2, tiga buah apel dengan angka 3, dan seterusnya. Semua ini dilakukan sampai anak benar-benar mengetahui konsep dan lambang bilangan dengan baik.

\section{Media Balok Cuisenaire}

1. Media Pembelajaran Untuk Anak Usia Dini

\section{a. Pengertian Media}

Menurut Arsyad (2009, hlm. 3) "kata media berasal dari bahasa latin medius yang secara harfiah berarti tengah, perantara atau pengantar." Menurut Gerlach \& Ely (dalam Arsyad 2009, hlm. 3) "media apabila dipahami secara garis besar adalah manusia, materi, atau kejadian yang membangun kondisi yang membuat siswa mampu memperoleh pengetahuan, keterampilan, atau sikap."

Menurut Hasnida (2014, hlm. 34) "media sering diidentikan dengan berbagai jenis peralatan atau sarana untuk menyajikan pesan."
Berdasarkan beberapa pendapat di atas, maka dapat dissimpulkan bahwa media adalah sarana yang digunakan untuk menyampaikan informasi atau pesan baik berupa manusia, materi, benda, atau suatu kejadian sehingga memperoleh suatu pengetahuan. Media pembelajaran merupakan suatu sarana penyampaian pesan atau informasi dimana dalam penyampaian informasinya guru berperan sebagai pemberi informasi pada anak, guru menggunakan berbagai media yang sesuai dengan tahap perkembangan anak, media yang digunakan oleh guru tersebut bertujuan untuk merangsang kemampuan dan keterampilan yang dimiliki anak yang nantinya anak tersebut akan memperoleh pengetahuan dan mendukung pada proses belajar anak.

\section{b. Pentingnya Media Untuk Anak Usia Dini}

Menurut Hasnida (2014, hlm. 49) Media pembelajaran pada dasarnya merupakan bagian integral dari keseluruhan komponen pembelajaran TK/PAUD. Tanpa media, maka proses pembelajaran tidak akan berjalan dengan efektif. Media pembelajaran untuk anak usia dini sangat penting, karena memiliki nilai-nilai sebagai berikut:

1) Memungkinkan anak berinteraksi secara langsung dengan lingkungannya.

2) Memungkinkan adanya keseragaman atau persepsi belajar pada masingmasing anak.

3) Membangkitkan motivasi belajar anak.

4) Menyajikan informasi belajar secara konsisten dan dapat diulang atau disimpan menurut kebutuhan.

5) Menyajikan pesan atau informasi belajar secara serempak bagi keseluruhan anak.

6) Mengatasi keterbatasan waktu dan ruang.

7) Mengontrol arah dan kecepatan belajar anak.

\section{Media Balok Cuisenaire}

Menurut Sudono (2006, hlm. 36) Balok cuisenaire yaitu balok sepuluh tingkat dari satu hingga sepuluh. Balok cuisenaire diciptakan oleh George Cuisenaire dari Belgia, karena ia 
mengamati sulitnya pemahaman matematika pada anak. Balok cuisenaire ini banyak dipergunakan di berbagai negara Eropa dan di beberapa negara bagian Australia.

Menurut George Cuisenaire (dalam Eliyawati 2005, hlm. 69):

Balok cuisenaire merupakan balok yang terdiri atas balok-balok yang dengan ukuran sebagai berikut: $1 \times 1 \times 1 \mathrm{~cm}$ berwarna kayu asli; $2 \times 1 \times 1 \mathrm{~cm}$ berwarna merah; $3 \times 1 \times 1$ $\mathrm{cm}$ berwarna hujau muda; $4 \mathrm{x} 1 \mathrm{x} 1 \mathrm{~cm}$ berwarna merah muda; $5 \times 1 \times 1 \mathrm{~cm}$ berwarna kuning; $6 \times 1 \times 1 \mathrm{~cm}$ berwarna hijau tua; $7 \times 1$ $\mathrm{x} 1 \mathrm{~cm}$ berwarna hitam; $8 \mathrm{x} 1 \mathrm{x} 1 \mathrm{~cm}$ berwarna coklat; $9 \times 1 \times 1 \mathrm{~cm}$ berwarna biru tua; $10 \times 1$ $\mathrm{x} 1 \mathrm{~cm}$ berwarna jingga.

Menurut Eliyawati (2005, hlm. 69) balok cuisenaire diciptakan untuk mengembangkan kemampuan berhitung pada anak, pengenalan bilangan, dan untuk peningkatan keterampilan anak dalam bernalar.

Balok cuisenaire ini merupakan salah satu Alat Permainan Edukatif (APE) untuk anak usia dini. Balok cuisenaire terbuat dari kayu dan dicat dengan warna yang bermacam-macam, balok tersebut merupakan media yang tahan lama Balok cuisenaire dalam penelitian ini telah dimodifikasi dengan ukuran yang lebih besar.

Sudono (2006, hlm. 21) menjelaskan bahwa balok cuisenaire bukan hanya sekedar mengembangkan konsep matematika, tetapi untuk pengembangan bahasa dan untuk peningkatan keterampilan anak.

\section{Langkah-Langkah Penggunaan Balok Cuisenaire Dalam Mengenal Lambang Bilangan 1-10}

Menurut Sudono (2006, hlm. 21) terdapat beberapa metode untuk lebih memahami konsep penggunaan balok cuisenaire yaitu dimulai dengan:

(1) Menghitung tanpa mengerti, asal urutannya sesuai (root counting), (2) Menghitung dan memadukan satu-satu (one to one correspondence), (3) Menghitung dengan menggunakan syair-syair yang sederhana yang didalamnya terdapat bilangan, (4) Menggunakan balok cuisenaire secara bebas dengan menggunakan bahasa, (5) Di tingkat Taman Kanak-kanak, anak membuat karpet berbentuk segi empat yang kemudian digunakan untuk mengungkapkan beberapa istilah matematis. Hal ini sangat membantu wawasan berpikir dan penguasaan bahasa anak.

Adapun langkah-langkah penggunaan balok cuisenaire dalam mengenal lambang bilangan 110, yaitu:

a. Guru mempersiapkan media yang akan digunakan untuk pembelajaran

b. Guru mengkondisikan anak sebelum pembelajaran dimulai

c. Guru menyampaikan tema pembelajaran kepada anak

d. Guru memperkenalkan media balok cuisenaire kepada anak

e. Guru mengajak anak untuk menghitung jumlah balok cuisenaire sesuai dengan jumlah setiap ruas balok cuisenaire tersebut, dengan cara meletakkan balok cuisenaire di depan anak dengan berkata satu, dua, tiga, empat, lima, dan seterusnya sampai sepuluh.

f. Setelah anak mampu menghitung setiap ruas balok cuisenaire, guru meminta anak untuk menyebut urutan bilangan 1-10 dan menunjuk lambang bilangan 1-10 pada gambar angka 1-10 sesuai bilangan pada jumlah setiap ruas balok cuisenaire.

g. Guru meminta anak untuk menghubungkan lambang bilangan 1-10 pada balok cuisenaire.

h. Guru selalu mendampingi anak, sehingga apabila ada anak yang mengalami kesulitan guru dapat membantunya.

\section{METODE PENELITIAN}

Setting penelitian dalam penelitian ini yaitu Penelitian Tindakan Kelas (Cassroom Action Research). Dalam hal ini guru yang mengajar perlu berkolaborasi dengan seorang atau tim peneliti. Pola pelaksanaan penelitian tindakan kelas ini adalah pola kolaboratif. Model yang digunakan dalam penelitian tindakan kelas ini 
adalah pengembangan dari model Kemmis dan Mc Taggart.

Dalam penelitian ini, subjek penelitiannya adalah guru dan seluruh anak di kelompok A (usia 4-5 tahun) Tahun Ajaran 2016/2017 di TK At-Toyyibah, dengan jumlah 12 anak, yaitu: 9 anak laki-laki dan 3 anak perempuan.

Penelitian ini dilaksanakan ke dalam tiga siklus dengan dua pertemuan setiap siklusnya. Langkah-langkah dalam setiap siklus sama, diantaranya perencanaan, pelaksanaan, observasi dan refleksi.

Teknik pengumpulan data dalam penelitian ini yaitu, observasi, wawancara, dan dokumentasi. Teknik analisis data dilakukan secara deskriftif kualitatif.

Instrumen penelitian yang digunakan yaitu lembar observasi, terdiri lembar observasi aktivitas guru dan anak.

\section{TEMUAN DAN PEMBAHASAN}

Berdasarkan hasil pengamatan, dapat diketahui bahwa kemampuan mengenal lambang bilangan 1-10 pada anak usia 4-5 tahun di TK At-Toyyibah masih rendah. Hasil observasi menunjukkan bahwa anak dalam menyebut urutan bilangan 1-10 sebesar 44\% anak yang mampu dan 56\% anak yang belum mampu, menunjuk lambang bilangan 1-10 sebesar 37\% anak yang mampu dan $63 \%$ anak yang beum mampu, serta menghubungkan lambang bilangan 1-10 dengan benda sebesar 25\% anak yang mampu dan $75 \%$ anak yang belum mampu dengan rata-rata persentase $35 \%$ anak yang mampu dan $65 \%$ anak yang belum mampu. Hal ini dikarenakan guru ketika melakukan kegiatan pembelajaran kurang bervariasi dalam penggunaan media pembelajarannya, kegiatan mengenal lambang bilangan 1-10 sebagian besar menggunakan Lembar Kerja Anak (LKA), majalah, buku tulis dan papan tulis. Bertumpu pada hal tersebut, kemampuan mengenal lambang bilangan 1-10 pada anak usia 4-5 tahun di TK At-Toyyibah perlu ditingkatkan lagi.
Tabel 1. Hasil Analisis Data Kemampuan Guru dalam Merencanakan Pembelajaran Pra

Tindakan,

Siklus I, II, dan III

\begin{tabular}{|c|c|c|c|c|c|c|c|c|c|}
\hline \multirow{2}{*}{$\begin{array}{l}\mathrm{N} \\
\mathrm{o}\end{array}$} & \multirow[t]{2}{*}{$\begin{array}{l}\text { Aspek/ } \\
\text { Indikator }\end{array}$} & \multicolumn{2}{|c|}{$\begin{array}{l}\text { Pra } \\
\text { Tind } \\
\text { akan }\end{array}$} & \multicolumn{2}{|c|}{$\begin{array}{l}\text { Siklus } \\
\text { I }\end{array}$} & \multicolumn{2}{|c|}{$\begin{array}{l}\text { Siklus } \\
\text { II }\end{array}$} & \multicolumn{2}{|c|}{$\begin{array}{l}\text { Siklus } \\
\text { III }\end{array}$} \\
\hline & & $\mathrm{f}$ & $\%$ & $\mathrm{f}$ & $\%$ & $\mathrm{f}$ & $\%$ & $\mathrm{f}$ & $\%$ \\
\hline 1 & $\begin{array}{l}\text { Merencanakan } \\
\text { kegiatan bidang } \\
\text { pengembangan (1- } \\
\text { 3) }\end{array}$ & 2 & $\begin{array}{l}5 \\
0 \\
\%\end{array}$ & $\begin{array}{l}2 \\
\text {, } \\
5\end{array}$ & $\begin{array}{l}5 \\
4 \\
\%\end{array}$ & 3 & $\begin{array}{l}7 \\
5 \\
\%\end{array}$ & $\begin{array}{l}3 \\
7\end{array}$ & $\begin{array}{l}9 \\
3 \\
\%\end{array}$ \\
\hline 2 & $\begin{array}{l}\text { Merencanakan } \\
\text { pengelolaan } \\
\text { kegiatan (4-9) }\end{array}$ & 2 & $\begin{array}{l}5 \\
0 \\
\%\end{array}$ & $\begin{array}{l}2 \\
5\end{array}$ & $\begin{array}{l}6 \\
3 \\
\%\end{array}$ & $\begin{array}{l}2 \\
7 \\
5\end{array}$ & $\begin{array}{l}6 \\
9 \\
\%\end{array}$ & $\begin{array}{l}3 \\
4\end{array}$ & $\begin{array}{l}8 \\
5 \\
\%\end{array}$ \\
\hline 3 & $\begin{array}{l}\text { Merencanakan } \\
\text { penilaian proses } \\
\text { dan hasil }(10-11)\end{array}$ & 2 & $\begin{array}{l}5 \\
0 \\
\%\end{array}$ & 3 & $\begin{array}{l}7 \\
5 \\
\%\end{array}$ & 3 & $\begin{array}{l}7 \\
5 \\
\%\end{array}$ & $\begin{array}{l}3 \\
5 \\
5\end{array}$ & $\begin{array}{l}8 \\
8 \\
\%\end{array}$ \\
\hline $\begin{array}{l}4 \\
.\end{array}$ & $\begin{array}{l}\text { Tampilan } \\
\text { dokumen (12-14) }\end{array}$ & 2 & $\begin{array}{l}5 \\
0 \\
\%\end{array}$ & $\begin{array}{l}2 \\
3\end{array}$ & $\begin{array}{l}5 \\
8 \\
\%\end{array}$ & $\begin{array}{l}2, \\
7\end{array}$ & $\begin{array}{l}6 \\
8 \\
\%\end{array}$ & $\begin{array}{l}3 \\
3\end{array}$ & $\begin{array}{l}8 \\
3 \\
\%\end{array}$ \\
\hline & Jumlah & 8 & $\begin{array}{l}2 \\
0 \\
0\end{array}$ & $\begin{array}{l}9 \\
9 \\
9 \\
5\end{array}$ & $\begin{array}{l}2 \\
5 \\
0\end{array}$ & $\begin{array}{l}1 \\
1 \\
4 \\
5\end{array}$ & $\begin{array}{l}2 \\
8 \\
7\end{array}$ & $\begin{array}{l}1 \\
3 \\
9 \\
9\end{array}$ & $\begin{array}{l}3 \\
4 \\
9\end{array}$ \\
\hline & Rata-Rata & 2 & $\begin{array}{l}5 \\
0 \\
\%\end{array}$ & $\begin{array}{l}2 \\
4 \\
4 \\
8\end{array}$ & $\begin{array}{l}6 \\
3 \\
\%\end{array}$ & $\begin{array}{l}2, \\
8 \\
6\end{array}$ & $\begin{array}{l}7 \\
2 \\
\%\end{array}$ & $\begin{array}{l}3 \\
4 \\
4 \\
7\end{array}$ & $\begin{array}{l}8 \\
7 \\
\%\end{array}$ \\
\hline & Kriteria & $\begin{array}{r}\mathrm{Se} \\
\mathrm{n}\end{array}$ & & & & & & & \\
\hline
\end{tabular}

\section{Keterangan:}

Kriteria:

a. Sangat Kurang, apabila kemampuan guru dalam melaksanakan pembelajaran mencapai persentase $0 \%-20 \%$

b. Kurang, apabila kemampuan guru dalam melaksanakan pembelajaran mencapai persentase $21 \%-40 \%$

c. Sedang, apabila kemampuan guru dalam melaksanakan pembelajaran mencapai persentase $41 \%-60 \%$

d. Baik, apabila kemampuan guru dalam melaksanakan pembelajaran mencapai persentase $61 \%-80 \%$

e. Sangat Baik, apabila kemampuan guru dalam melaksanakan pem5belajaran mencapai persentase $81 \%-100 \%$ 
Berdasarkan tabel 1, menunjukkan kemampuan guru dalam merencanakan pembelajaran dari pra tindakan ke siklus I, siklus I ke siklus II dan dari Siklus II ke siklus III mengalami peningkatan yang signifikan. Hasil observasi menunjukkan peningkatan dari skor pada pra tindakan sebesar 2 dengan persentase $50 \%$ ke siklus I rata-rata skor 2,38 dengan persentase $63 \%$ berkriteria sedang, rata-rata skor dari siklus I 2,48 dengan persentase 63\% berkriteria baik ke siklus II sebesar 2,86 dengan persentase $72 \%$ berkriteria baik. Dan dari siklus II sebesar 2,86 dengan persentase 72\% berkriteria baik ke siklus III sebesar 3,47 dengan persentase $87 \%$ berkriteria sangat baik dan telah mencapai indikator keberhasilan.

Tabel 2. Hasil Analisis Data Kemampuan Guru dalam Melaksanakan Pembelajaran Pra Tindakan,

Siklus I, II, dan III

\begin{tabular}{|c|c|c|c|c|c|c|c|c|c|}
\hline \multirow{2}{*}{$\begin{array}{l}\mathrm{N} \\
\mathrm{O}\end{array}$} & \multirow{2}{*}{$\begin{array}{l}\text { Aspek/Indi } \\
\text { kator }\end{array}$} & \multicolumn{2}{|c|}{$\begin{array}{c}\text { Pra } \\
\text { Tin } \\
\mathrm{d}\end{array}$} & \multicolumn{2}{|c|}{$\begin{array}{l}\text { Siklus } \\
\text { I }\end{array}$} & \multicolumn{2}{|c|}{$\begin{array}{l}\text { Siklus } \\
\text { II }\end{array}$} & \multicolumn{2}{|c|}{$\begin{array}{c}\text { Siklus } \\
\text { III }\end{array}$} \\
\hline & & $\mathrm{f}$ & $\%$ & $\mathrm{f}$ & $\%$ & $\mathrm{f}$ & $\%$ & $\mathrm{f}$ & $\%$ \\
\hline 1 & $\begin{array}{l}\text { Kegiatan } \\
\text { awal } \\
\text { pembelaja } \\
\text { ran }(1-3)\end{array}$ & 2 & $\begin{array}{l}5 \\
0 \\
\%\end{array}$ & 2 & 5 & 3 & 7 & 3 & 8 \\
\hline 2 & $\begin{array}{l}\text { Kegiatan } \\
\text { inti } \\
\text { pembelaja } \\
\text { ran (4-23) }\end{array}$ & 2 & $\begin{array}{l}5 \\
0 \\
\%\end{array}$ & 2 & 6 & 3 & 7 & 3 & 8 \\
\hline 3 & $\begin{array}{l}\text { Kegiatan } \\
\text { akhir (24- } \\
25)\end{array}$ & 2 & $\begin{array}{l}5 \\
0 \\
\%\end{array}$ & 2 & 5 & 2 & 6 & 3 & 7 \\
\hline & Jumlah & 6 & 2 & 6 & 1 & 8 & 2 & 9 & 2 \\
\hline & Rata-Rata & 2 & 5 & 2 & 5 & 2 & 7 & 3 & 8 \\
\hline
\end{tabular}

\begin{tabular}{|c|c|c|c|c|}
\hline Kriteria & $\begin{array}{c}\text { Sed } \\
\text { ang }\end{array}$ & Baik & Baik & $\begin{array}{c}\text { Sanga } \\
\text { t Baik }\end{array}$ \\
\hline
\end{tabular}

\section{Keterangan:}

Kriteria:

a. Sangat Kurang, apabila kemampuan guru dalam melaksanakan pembelajaran mencapai persentase $0 \%-20 \%$

b. Kurang, apabila kemampuan guru dalam melaksanakan pembelajaran mencapai persentase $21 \%-40 \%$

c. Sedang, apabila kemampuan guru dalam melaksanakan pembelajaran mencapai persentase $41 \%-60 \%$

d. Baik, apabila kemampuan guru dalam melaksanakan pembelajaran mencapai persentase $61 \%-80 \%$

e. Sangat Baik, apabila kemampuan guru dalam melaksanakan pem5belajaran mencapai persentase $81 \%-100 \%$

Berdasarkan tabel 2, menunjukkan kemampuan guru dalam melaksanakan pembelajaran mengalami peningkatan dari pratindakan ke siklus I, siklus I ke siklus II, dan dari siklus II ke siklus III yang signifikan. Hasil observasi menunjukkan peningkatan dari skor pratindakan sebesar 2 dengan persentase 50\% berkriteria sedang ke siklus I rata-rata sebesar 2,28 dengan persentase $57 \%$ berkriteria sedang, dari rata-rata skor pada siklus I sebesar 2,28 dengan persentase $57 \%$ berkriteria baik ke siklus II sebesar 2,88 dengan persentase 72\% berkriteria baik. Kemudian Dari siklus II sebesar 2,88 dengan persentase $72 \%$ berkriteria baik ke siklus III sebesar 3,28 dengan persentase $82 \%$ berkriteria sangat baik dan telah mencapai indikator keberhasilan.

Tabel 3. Hasil Analisis Data Kemampuan Guru dalam Penggunaan Media Balok Cuisenaire untuk Meningkatkan Kemampuan Mengenal Lambang Bilangan 1-10 pada Anak Usia 4-5 Siklus I, II, dan III

\begin{tabular}{|c|c|c|c|}
\hline Variabel & Aspek & $\begin{array}{c}\text { Rata- } \\
\text { Rata } \\
\text { Perse } \\
\end{array}$ & $\begin{array}{l}\text { Rata- } \\
\text { Rata } \\
\text { Perse }\end{array}$ \\
\hline
\end{tabular}




\begin{tabular}{ccccc}
\hline & \multicolumn{2}{c}{$\begin{array}{c}\text { ntase } \\
\text { Siklu } \\
\text { s I }\end{array}$} & $\begin{array}{c}\text { ntase } \\
\text { Siklu } \\
\text { s II }\end{array}$ & $\begin{array}{c}\text { ntase } \\
\text { Siklu } \\
\text { s III }\end{array}$ \\
\hline & $\begin{array}{c}\text { Persia } \\
\text { pan }\end{array}$ & $50 \%$ & $70 \%$ & $85 \%$ \\
\cline { 2 - 5 } & $\begin{array}{c}\text { Pengg } \\
\text { unaan }\end{array}$ & $40 \%$ & $65 \%$ & $85 \%$ \\
\cline { 2 - 5 } & $\begin{array}{c}\text { Penilai } \\
\text { an }\end{array}$ & $50 \%$ & $75 \%$ & $94 \%$ \\
\cline { 2 - 5 } $\begin{array}{c}\text { Penggunaan } \\
\text { Cuisenaire }\end{array}$ & $\begin{array}{c}\text { Jumla } \\
\text { h }\end{array}$ & 140 & 210 & 264 \\
\cline { 2 - 5 } & $\begin{array}{c}\text { Rata- } \\
\text { Rata }\end{array}$ & $47 \%$ & $70 \%$ & $88 \%$ \\
\cline { 2 - 5 } & $\begin{array}{c}\text { Kriteri } \\
\text { a }\end{array}$ & $\begin{array}{c}\text { Seda } \\
\text { ng }\end{array}$ & Baik & $\begin{array}{c}\text { Sang } \\
\text { at } \\
\text { Baik }\end{array}$ \\
\hline
\end{tabular}

\section{Keterangan:}

Kriteria:

a. Sangat Kurang, apabila kemampuan guru dalam melaksanakan pembelajaran mencapai persentase 0\%-20\%

b. Kurang, apabila kemampuan guru dalam melaksanakan pembelajaran mencapai persentase $21 \%-40 \%$

c. Sedang, apabila kemampuan guru dalam melaksanakan pembelajaran mencapai persentase $41 \%-60 \%$

d. Baik, apabila kemampuan guru dalam melaksanakan pembelajaran mencapai persentase $61 \%-80 \%$

e. Sangat Baik, apabila kemampuan guru dalam melaksanakan pem5belajaran mencapai persentase $81 \%-100 \%$

Berdasarkan tabel 3, menunjukkan kemampuan guru dalam menggunakan media balok cuisenaire untuk meningkatkan kemampuan mengenal lambang bilangan 1-10 pada anak usia 4-5 tahun juga mengalami peningkatan yang signifikan setiap siklusnya. Hasil observasi menunjukkan peningkatan dari rata-rata persentase siklus I sebesar $47 \%$ dengan kriteria sedang ke siklus II sebesar $70 \%$ dengan kriteria baik. Dan dari siklus II sebesar $70 \%$ dengan kriteria baik ke siklus III sebesar $88 \%$ dengan kriteria sangat baik dan telah mencapai indikator keberhasilan.
Tabel 4. Hasil Analisis Data Kemampuan Mengenal Lambang Bilangan 1-10 Pada Anak Usia 4-5 Tahun Pra Tindakan, Siklus I, II, dan III

\begin{tabular}{|c|c|c|c|c|c|c|c|c|c|}
\hline \multirow{2}{*}{$\begin{array}{l}N \\
0\end{array}$} & \multirow[t]{2}{*}{ Aspek } & \multicolumn{2}{|c|}{$\begin{array}{c}\text { Pra } \\
\text { Tinda } \\
\text { kan }\end{array}$} & \multicolumn{2}{|c|}{$\begin{array}{l}\text { Siklus } \\
\text { I }\end{array}$} & \multicolumn{2}{|c|}{$\begin{array}{c}\text { Siklus } \\
\text { II }\end{array}$} & \multicolumn{2}{|c|}{$\begin{array}{c}\text { Siklus } \\
\text { III }\end{array}$} \\
\hline & & & $\begin{array}{l}\mathrm{B} \\
\mathrm{M}\end{array}$ & M & $\begin{array}{l}\mathrm{B} \\
\mathrm{M}\end{array}$ & M & $\begin{array}{l}\text { B } \\
\text { M }\end{array}$ & $\mathrm{M}$ & $\begin{array}{l}\mathrm{B} \\
\mathrm{M}\end{array}$ \\
\hline 1 & $\begin{array}{l}\text { Menye } \\
\text { but } \\
\text { urutan } \\
\text { bilanga } \\
\text { n } 1-10\end{array}$ & $\begin{array}{l}4 \\
2 \\
\%\end{array}$ & $\begin{array}{l}5 \\
8 \\
\%\end{array}$ & $\begin{array}{l}4 \\
4 \\
\%\end{array}$ & $\begin{array}{l}5 \\
6 \\
\%\end{array}$ & $\begin{array}{l}9 \\
2 \\
\%\end{array}$ & $\begin{array}{l}8 \\
\%\end{array}$ & $\begin{array}{l}9 \\
2 \\
\%\end{array}$ & $\begin{array}{l}8 \\
\%\end{array}$ \\
\hline 2 & $\begin{array}{l}\text { Menun } \\
\text { juk } \\
\text { lamban } \\
\text { g } \\
\text { bilanga } \\
\text { n } 1-10\end{array}$ & $\begin{array}{l}3 \\
7 \\
\%\end{array}$ & $\begin{array}{l}6 \\
3 \\
\%\end{array}$ & $\begin{array}{l}3 \\
7 \\
\%\end{array}$ & $\begin{array}{l}6 \\
3 \\
\%\end{array}$ & $\begin{array}{l}8 \\
8 \\
\%\end{array}$ & $\begin{array}{l}1 \\
2 \\
\%\end{array}$ & $\begin{array}{l}8 \\
8 \\
\%\end{array}$ & $\begin{array}{l}1 \\
2 \\
\%\end{array}$ \\
\hline 3 & $\begin{array}{l}\text { Mengh } \\
\text { ubungk } \\
\text { an } \\
\text { lamban } \\
\mathrm{g} \\
\text { bilanga } \\
\text { n } 1-10 \\
\text { dengan } \\
\text { benda }\end{array}$ & $\begin{array}{l}2 \\
5 \\
\%\end{array}$ & $\begin{array}{l}7 \\
5 \\
\%\end{array}$ & $\begin{array}{l}2 \\
7 \\
\%\end{array}$ & $\begin{array}{l}7 \\
3 \\
\%\end{array}$ & $\begin{array}{l}8 \\
3 \\
\%\end{array}$ & $\begin{array}{l}1 \\
7 \\
\%\end{array}$ & $\begin{array}{l}8 \\
3 \\
\%\end{array}$ & $\begin{array}{c}1 \\
7 \\
\%\end{array}$ \\
\hline & $\begin{array}{l}\text { ata-Rata } \\
\text { etercapai } \\
\text { an Anak }\end{array}$ & $\begin{array}{l}3 \\
5 \\
\% \\
\end{array}$ & $\begin{array}{l}6 \\
5 \\
\%\end{array}$ & $\begin{array}{l}3 \\
6 \\
\% \\
\end{array}$ & $\begin{array}{l}6 \\
4 \\
\% \\
\end{array}$ & $\begin{array}{l}3 \\
5 \\
\%\end{array}$ & $\begin{array}{l}8 \\
8 \\
\% \\
\end{array}$ & $\begin{array}{l}1 \\
2 \\
\% \\
\end{array}$ & $\begin{array}{l}1 \\
2 \\
\% \\
\end{array}$ \\
\hline & Kriteria & $\begin{array}{c}\mathrm{Ml} \\
\mathrm{Be} \\
\mathrm{mb}\end{array}$ & & & $\begin{array}{l}\text { lai } \\
\text { ke } \\
\text { ang }\end{array}$ & & $\begin{array}{l}\text { ke } \\
\text { ang } \\
\text { uai } \\
\text { ap }\end{array}$ & $\begin{array}{l}\mathrm{Be} \\
\mathrm{mb} \\
\mathrm{Se} \\
\mathrm{Ha} \\
\mathrm{c}\end{array}$ & $\begin{array}{l}\text { rke } \\
\text { ang } \\
\text { uai } \\
\text { rap } \\
\text { n }\end{array}$ \\
\hline
\end{tabular}

Berdasarkan tabel 4, menunjukkan kemampuan mengenal lambang bilangan 1-10 pada anak usia 4-5 tahun juga mengalami peningkatan yang signifikan.dari pra tindakan ke siklus I, siklus I ke siklus II, dan dari siklus II ke siklus III. Hasil observasi dari pra tindakan ke siklus I, kemampuan menunjukkan peningkatan walaupun hanya $1 \%$ dengan rata-rata persentase pada pra tindakan sebesar $35 \%$ anak yang mampu dan $65 \%$ anak yang belum mampu ke siklus I sebesar 34\% anak yang mampu dan 64\% 
anak yang belum mampu. Dari siklus I rata-rata persentase sebesar 34\% anak yang mampu ke siklus sebesar $65 \%$ anak yang mampu dan $35 \%$ anak yang belum mampu. Kemudian dari siklus II rata-rata persentase sebesar sebesar $65 \%$ anak yang mampu dan $35 \%$ anak yang belum mampu ke siklus II sebesar $83 \%$ anak yang mampu dan $17 \%$ anak yang belum mampu dan telah mencapai indikator keberhasilan. Untuk lebih jelasnya dapat dilihat pada grafik berikut ini:

Gambar 1. Peningkatan Kemampuan Mengenal Lambang Bilangan 1-10 Pada Anak Usia 4-5 Tahun Pra Tindakan, Siklus I, Siklus II dan Siklus III

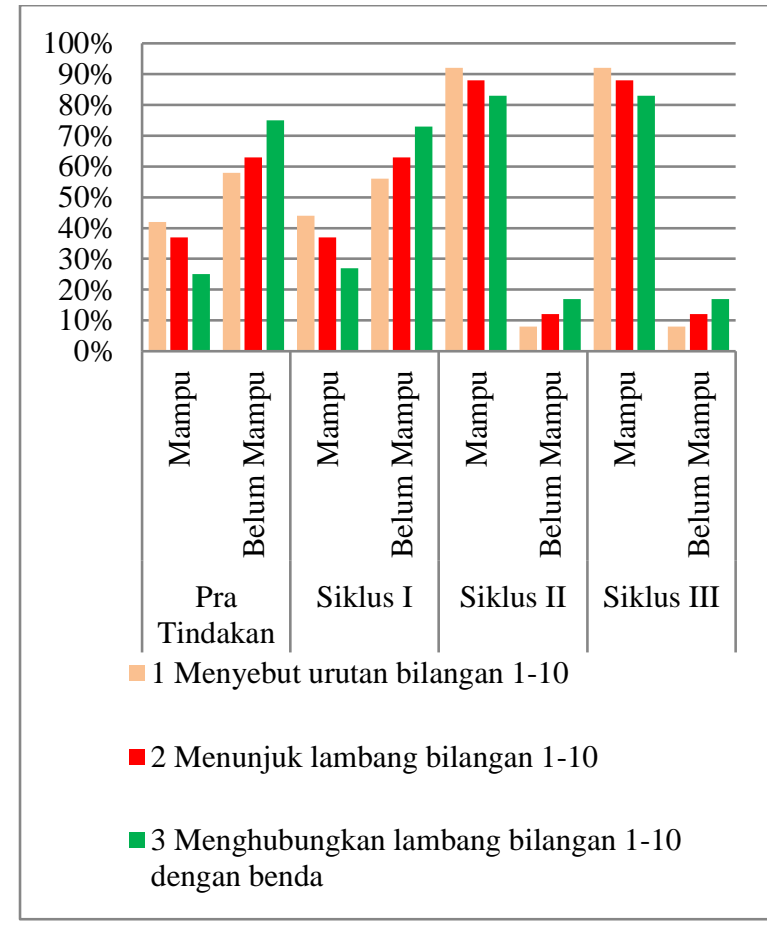

Berdasarkan uraian di atas, dapat disimpulkan bahwa media balok cuisenaire dapat meningkatkan kemampuan mengenal lambang bilangan 1-10 pada anak usia 4-5 tahun di TK At-Toyyibah, Kecamatan Sukarame, Kabupaten Tasikmalaya.

\section{KESIMPULAN}

Berdasarkan hasil penelitian yang dilaksanakan melalui tiga siklus tentang peningkatan kemampuan mengenal lambang bilangan 1-10 melalui media balok cuisenaire pada anak usia 4-5 tahun di TK At-Toyyibah, Kecamatan. Sukarame, Kabupaten. Tasikmalaya, maka peneliti mengambil kesimpulan sebagai berikut:

1. Perencanaan kegiatan dengan menggunakan media balok cuisenaire sebagai cara untuk meningkatkan kemampuan mengenal lambang bilangan 1-10 melalui media balok cuisenaire pada anak usia 4-5 tahun di TK At-Toyyibah, Kecamatan. Sukarame, Kabupaten. Tasikmalaya, yang telah disusun oleh peneliti telah mencapai indikator keberhasilan. Peneliti membuat Rencana Pelaksanaan Pembelajaran Harian (RPPH) yang digunakan sebagai pedoman dalam pelaksanaan pembelajaran. Selain RPPH, peneliti juga menyiapkan lembar observasi aktivitas guru dan lembar observasi aktivitas anak. Kemampuan guru dalam merencanakan dan melaksanakan pembelajaran mengalami peningkatan dari siklus I ke siklus II, dan dari siklus II ke siklus III. Hal tersebut terjadi karena ada perbaikan-perbaikan pada setiap siklusnya dan untuk mengurangi kendala yang mungkin akan terjadi pada siklus berikutnya.

2. Penggunaan media balok cuisenaire merupakan salah satu penggunaan media yang bertujuan untuk meningkatkan kemampuan mengenal lambang bilangan 110 pada anak usia 4-5 tahun di TK AtToyyibah, Kecamatan. Sukarame, Kabupaten. Tasikmalaya, Kemampuan guru dalam menggunakan media balok cuisenaire mengalami peningkatan dari siklus I ke siklus II, dan dari siklus II ke siklus III. Hal tersebut terjadi karena adanya perbaikan-perbaikan pada setiap siklusnya dan untuk mengurangi kendala yang mungkin akan terjadi pada siklus berikutnya.

3. Kemampuan mengenal lambang bilangan 110 pada anak usia 4-5 tahun di TK AtToyyibah, Kecamatan. Sukarame, Kabupaten. Tasikmalaya, diketahui 
meningkat setelah adanya penggunaan media balok cuisenaire. Hal ini dapat dibuktikan dengan adanya peningkatan dari pra tindakan ke siklus I, dari siklus I ke siklus II, dan dari siklus II ke siklus III.

Berdasarkan uraian di atas, dapat disimpulkan bahwa media balok cuisenaire dapat meningkatkan kemampuan mengenal lambang bilangan 1-10 pada anak usia 4-5 tahun di TK At-Toyyibah, Kecamatan Sukarame, Kabupaten Tasikmalaya.

\section{SARAN}

Dalam rangka meningkatkan kualitas pembelajaran untuk meningkatkan kemampuan mengenal lambang bilangan 1-10 pada anak, maka peneliti menyampaikan beberapa saran sebagai berikut:

1. Dalam melaksanakan pembelajaran untuk meningkatkan kemampuan mengenal lambang bilangan 1-10 pada anak, guru dapat menggunakan media balok cuisenaire sebagai media alternatif dalam kegiatan pembelajarannya. Karena dengan menggunakan media balok cuisenaire ini, membuat anak aktif dalam berfikir, selain itu anak memperoleh pengalaman praktis serta keterampilan dalam menggunakan media pembelajaran.

2. Dengan media balok cuisenaire, tidak hanya dapat mengembangkan kemampuan mengenal lambang bilangan 1-10 pada anak saja, tetapi dapat mengenal bentuk, warna, dan melatih daya ingat anak. Sehingga, dapat dijadikan alternatif bagi peneliti selanjutnya untuk mengembangkan aspek perkembangan yang lainnya.

\section{DAFTAR PUSTAKA}

Arikunto, S. (2006). Prosedur Penelitian Suatu Tindakan Praktik. Jakarta: PT Rineka Cipta.

Arsyad, A. (2009). Media Pembelajaran. Jakarta: Rajawali Pers.
Blevins-Knabe, B. \& Austin, A.M.B. (2016). Early Childhood Mathematics Skill Development in the Home Environment. Switzerland: Springer.

Cross, C.T., dkk. (2009). Mathematics learning in early childhood. Washington DC: The National Academies Press.

Djamarah, S.B. (2013). Strategi Belajar Mengajar. Jakarta: Rineka Cipta.

Depdiknas. (2003). Undang-Undang Sistem Pendidikan Nasional Dan Peraturan pelaksanaannya. Jakarta: Departemen Pendidikan Nasional.

Eliyawati, C. (2005). Pemilihan dan Pengembangan Sumber belajar Untuk Anak Usia Dini. Jakarta: Depdiknas.

Hasanah, N.S. (2014). Upaya Meningkatkan Kemampuan Mengenal Lambang Bilangan Melalui Media Pemancingan Ikan Pada Anak, 2 (2), hlm. 48.

Hasnida. (2014). Media Pembelajaran Kreatif. Jakarta Timur: PT. Luxima Metro Media.

Jamaris, M. (2006). Perkembangan Dan Pengembangan Anak Usia Taman Kanak-Kanak. Jakarta: Grasindo.

Kemendikbud. (2014). Peraturan Menteri Pendidikan Dan Kebudayaan Republik Indonesia Nomor 137 Tentang Standar Nasional Pendidikan Anak Usia Dini. Jakarta: Kementerian Pendidikan Dan Kebudayaan.

Mulyana, E.H. \& Nur, L. (2015). Statistika Deskriftif. Prodi Guru Pendidikan Anak Usia Dini UPI Kampus Tasikmalaya: Tidak diterbitkan.

Negoro, ST. \& Harahap, B. (1998). Ensiklopedia Matematika. Jakarta: Ghalia Indonesia.

Perry, B., dkk. (2015). Mathematics and Transition to School. Singapore: Springer Science+Business Media.

Ramli, M. (2005). Pendampingan Perkembangan Anak Usia Dini. Jakarta: Depdiknas.

Sofia Hartati. (2005). Perkembangan Belajar pada Anak Usia Dini. Jakarta: Departemen Pendidikan Nasional, 
Direktorat Jenderal Pendidikan Tinggi, Direktorat Pendidikan Tenaga Kependidikan dan Ketenagaan Perguruan Tinggi.

Suardiman, S. P. (2003). Metode Pengembangan Daya Pikir dan Daya Cipta Untuk Anak Usia Dini. Yogyakarta: FIP UNY.

Sudaryanti. (2006). Pengenalan Matematika Anak Usia Dini. Yogyakarta: UNY Press.

Sudono, A. (2006). Sumber Belajar Dan Alat Permainan. Jakarta: PT. Grasindo.

Sujiono, Y. N. (2013). Konsep Dasar Pendidikan Anak Usia Dini. Jakarta: PT. Indeks.

Suyanto, S. (2005). Dasar-Dasar Pendidikan Anak Usia Dini. Yogyakarta: Hikayat Publishing.

Tim Satgas PPL. 2016. Pedoman Program Pengalaman Lapangan (PPL) Tahun akademik 2016-2017. UPI Kampus Tasikmalaya: Tidak diterbitkan.

Upton P. ( 2012). Psikologi Perkembangan. Jakarta: Erlangga.

Vandermaas-Peeker, M. \& McClain, C. 2015. Internasional Journal of Early Chilhood Environmental Education. An Observational Study of Preschoolers' Math and Science Experiences in a Garden 3 (1), hlm. 9.

Yang, D. (2003). International Journal of Science and Mathematics Education. Teaching and Learning Number SenseAn Intervention Study of Fifth Grade Students in Taiwan 1 (2), hlm. 115-134.

Yus, A. (2005). Penilaian Perkembangan Belajar Anak Taman Kanak-Kanak. Jakarta: Depdiknas.

Sumber internet:

Tn. (2014). Standar Pembuat Media Pembelajaran Paud. [Online]. Di akses dari http://paudjateng.xahzgs.com/2015/08/st andar-pembuatan-media pembelajaranpaud.html. 